type. From the present distribution of the shortheaded races we may regard Russia as the most probable cradle of this race. The brachycephalic fairhaired European may be regarded as the latest and perhaps highest product in evolving humanity. Time will show that the brachycephalic peoples of Europe are essentially of Slavonic origin, and that brachycephaly will prove to be a Mendelian dominant in the fusion of long- and short-headed peoples.

Dr. v. Buttel-Reepen adopts Dr. Penck's three intermissions of the Glacial period-a first, second, and third; and in the tentative condition of our knowledge that division is as good as another. To the beginning of this period he assigns Homo Heidelbergensis, known from his mandible only and by the Eoliths ascribed to him. A minute study of this mandible leaves no doubt that Homo Heidelbergensis must be assigned to the Neanderthal race. Remains of this race are also ascribed to the second interval and the third succeeding Ice age-a period estimated at 200,000 to 400,000 years. If such a period is approximately correct, then it is wonderful that the type remained so constant throughout such a vast interval of time. We know of only nine crania of the race, and the limb bones of only five or six individuals, and in all of them the state of preservation is incomplete.

The rarity of such specimens probably explains the extraordinary sum paid by the Museum für Völkerkunde, in Berlin, for the skeleton discovered by Herr $\mathrm{O}$. Hauser near Le Moustier in 1908-a price, according to Dr. Buttel-Reepen, amounting to r6o,000 marks. The skull of this skeleton, like that found at Chapelle-aux-Saints, was so broken that in neither case has an approximately accurate reconstruction been made. Indeed, the only cranium which is nearly complete and intact is that found at Gibraltar so long ago as 1848 - nine years before the discovery of the Neanderthal calvaria. This cranium, which Dr. Buttel-Reepen regards as of little scientific value, is, in the opinion of the writar, the most primitive and therefore probably the oldest of all the remains yet found of the remarkable Neanderthal race. It is the only one which shows a cranial capacity decidedly below the average of modern Europeans; the palate, and especially the teeth, are of the most primitive form known in this race. In such a long period of time as that ascribed to the Ice age, there must have been a succession of many races, and in the remains found at Krapina (Croatia), and at Spy (Belgium), we see what is apparently a mixture of older and more recent forms.

In the third interval of the Ice age the Neanderthal race apparently disappeared; his successor at present is supposed to be the type of man found at Gally Hill in Kent, and at Brünn in Moravia-a long- and narrow-headed race, so unlike the Neanderthal that Prof. Klaatch propounded the theory of a multiple simian origin for human races-a theory which Dr. v. Buttel-Reepen says must be taken cum grano salis. The remains found in the Grimaldi cave, near Mentone, and the Cro-Magnon race are also assigned to the close of the Glacial period. The Cro-Magnon race, which thus early appeared in Europe, is from a physical point of view, and also as regards the cranial capacity, one of the finest races of mankind ever evolved. The bearing of all recent discoveries of ancient man in Europe, both as regards his physical structure and his culture, is to remove the beginning of humanity into a more remote past-one which reaches into the Pliocene period at least.

Dr. Buttel-Reepen, like of many of his German colleagues, is inclined to assign the skull discovered in Gough's cavern, Cheddar, and described by $\mathrm{Mr}$. H. N. Davies in 1904, to the Palæolithic period. NO. 2 I9O, VOL. 87]
There can be no doubt this is an error, for the cranium in question is an example of the "river-bed" typethe characteristic form in England during the early Neolithic period. The Tilbury skull, and one recently found in a Derbyshire cave by the Rev. E. H. Mullins, are also of this type.

A. KeITH.

COAL DISCOVERIES IN BRITISH COLUMBIA,

THE announcement, made in a special article in

The Times of October 14, on "Coal in British Columbia," that an "immense body of anthracite coal exists at the head-waters of the Skeena . . ." to quote the words used in the telegram from the Minister of Mines of that province, need cause no surprise when it is considered how little is yet known about the mineral resources of the vast territories comprised within the Dominion of Canada. If the figures given by Reuter may be taken as trustworthy, 2100 square miles and 43,000,000 tons per square mile, the estimated coal resources of the province leap up in a single bound from $40,225,000,000$ tons, as estimated in I9I0, to $130,5^{25}, 000,000$ tons, the addition amounting to about three times the quantity estimated to be contained in our own South Wales coalfield.

Very little information appears to have been allowed to leak out regarding this immense coalfield almost up to the moment when publicity was given to the foregoing statements. All that is said about it in the annual report of the Minister of Mines for the year ending December 3I, I9Io, is that "the anthracite district around the head-waters of the Skeena continues to attract attention" (p. K88). Again, on p. $\mathrm{K}_{17} 7$ of the same document a summary is given in the form of a table of the estimated coal-content of the various known coal areas in British Columbia, extracted from a paper read by Mr. D. W. Dowling, of the Geological Survey, before the Canadian Mining Institute at the Quebec meeting in March, I9II, in which the Skeena River is credited with sixteen square miles and 6r,000,000 tons of anthracite. Lastly, when the present writer had the pleasure of meeting $\mathrm{Mr}$. McEvoy (mentioned in the telegram of the Minister of Mines) in Toronto on March 7 last, nothing that he can recollect was said to give him any clue to the vastness of the coalfield which Mr. McEvoy was then about to re-visit.

In the table referred to above the names of twelve separate coalfields are given, probably all of Cretaceous age, containing 39,674 million tons of bituminous coal; three, probably of Tertiary age, containing 490 million tons of lignite; and one, the Skeena River coalfield, the geological age of which is not mentioned, containing sixty-one million tons of anthracite. The largest areas are those of Comox, 300 squares miles; Nanaimo, 350; Elk River, 230; Elk River north, I40; Graham Island, 60 , all containing bituminous coal; and Graham Island, roo, lignite. Although the areas of Comox and Nanaimo fields are the greatest, the assumed thickness of coal in each, namely, six feet, puts their estimated reserves far behind those of the two Elk River fields, each with roo feet of coal distributed in a number of separate seams. As stated in the article in The Times, the two first are in Vancouver Island. The seams of coal, Douglas and Wellington, with a rider from two to three feet thick under the first, and a similar rider from two to four feet thick above the second, crop out at a greater or less distance from the shore, not exceeding six or seven miles perhaps at most, and dip under the sea in the Strait of Georgia and under the small islands near the shore. The two last, Elk River and Elk River north, are cut through by the defiles in, and not far from, the watershed of the Rocky Mountains, and 
consequently many of the seams of coal are accessible by means of day-levels. The present writer would have thought that a greater thickness than six feet of coal could have been attributed, at any rate to the seams in the Nanaimo coalfield, as the Douglas seam occurs in the form of lenticular masses, the maximum thickness of which attains as much as twenty-six and twenty-eight feet at some points, and as the Wellington seam, which underlies it at a depth of seven hundred to one thousand feet, is from three to six feet thick.

The following analyses will serve to show the character of the bituminous coals referred to above :-

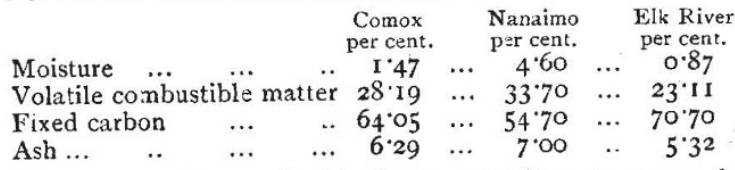

The proportions of all these constituents vary in each of the coalfields, the moisture attaining in some cases as much as 7 per cent, volatile combustible matter more than 40 per cent., and ash ro per cent. and more. Some of the seams make good coke, when the proportion of moisture is low enough (not exceeding 2 per cent.).

The produce of the Vancouver Island Collieries is in demand along the western coast of America; that of the Elk River Collieries supplies smelting works in the United States, railways, and so on.

The produce of the Skeena River Collieries will have about 180 miles to travel to the coast at Prince Rupert, and will thereafter have to compete with the bituminous coals of Vancouver and some of the other islands along the coast, which can ship their coal directly into the holds of the ships which use it.

It is to be hoped that in the great field the existence of which has been foreshadowed, some of the supposed anthracite will be found to contain at least i2 per cent. volatile combustible matter, as "drier" coals and true anthracites, containing from 3 per cent. to 6 per cent., are not considered suitable for steam-raising purposes in European countries, on account of their slow rate of combustion, 'although Pennsylvanian anthracite seems to be quite acceptable in some parts of the United States.

\section{DR. HUGHLINGS JACKSON, F.R.S.}

THE recent death of Dr. Hughlings Jackson has called forth that widespread recognition amongst men of science which his modesty and retiring nature rendered impossible during his lifetime. To many, and particularly to workers in scientific fields remote from medicine, his name is unknown, and yet, although he never performed an experiment, no one man has so profoundly influenced the growth of our knowledge of the functions of the nervous system.

John Hughlings Jackson was born in 1835 , at Green Hamerton, in Yorkshire, and began the study of medicine at York. After a short period as a student at St. Bartholomew's Hospital, he became qualified to practise medicine in 1856 , and then returned to York for two years as house-surgeon to the dispensary. In 1862 he was appointed assistant physician to the National Hospital for the Paralysed and Epileptic, and in 1863 he became assistant physician to the London Hospital. These are the material facts in Dr. Jackson's outwardly uneventful life.

At the National Hospital he came in contact with two men who influenced the direction of his thoughts, Brown-Séquard, from whom he acquired a knowledge of the recent work of French physiologists, and Lockhart Clarke, whose beautiful microscopic preparations taught him the minute anatomy of the nervous system. But in his early lectures, delivered between IS64 and I868, he showed how quickly he had found that path which was to lead him by consecutive steps to his greatest generalisations. In 1864 he had already shown that paralysis of the right half of the body was associated, in most cases, with loss of speech, and characteristically gave the whole credit to Broca, whose work had appeared shortly before his lecture. Broca's observations were essentially anatomical, and are still the subject of dispute, but Jackson described forms of disturbed speech associated with hemiplegia, which stand untouched to-day. In 1866, he formulated the condition now known as apraxia, and repeatedly demonstrated cases of this disturbance to his pupils in the wards of the hospital. But he was forty years before his time, and apraxia was not generally recognised until its rediscovery by Continental observers.

At that time all work on the functions of the nervous system was dominated by the brilliant discoveries of the French School of Physiology, and Jackson's idea that convulsions arose from some change in the cerebrum and usually from a focus within the territory of the Sylvian artery was passed over in contemptuous silence. But when Hitzig and Fritsch showed, in 1870 , that stimulation of the cortex could produce movements, Jackson's views came to the front, and local convulsions are now called by his name.

Step by step we can watch the growth of his great generalisation put forward in the Croonian lectures of I 884 on "Evolution and Dissolution of the Nervous System." He showed that in hemiplegia movements and not muscles were affected, for the brain is not dealing with tools but with functions. Thence he passed to the idea of "levels" in the nervous system, each of which represented a higher evolution; passage from one level to that above it was always from the general to the special in function, and from the simple to the complex in structure. Dissolution produced by disease or by experiment occurred in the inverse order, and the removal of the highest level set free the activities of those below. To this view Jackson gave the widest application, and explained the rigidity of limbs paralysed from cerebral disease by the over-action of uncontrolled centres in the cerebellum and spinal cord. So far back as $187 \%$, he laid down that "the cerebellum is the centre for continuous movements and the cerebrum for changing movements," and so formulated the modern doctrine of the tonic nature of cerebellar activity.

These wide-reaching generalisations have not yet received their full application, but they permeate modern neurology; and the position of the English School is due largely to Dr. Jackson's stimulating influence and generous self-effacement.

H. H.

\section{AUGUSTE MICHEL LEEVY.}

○ September 25, Auguste Michel Lévy, director of the Geological Survey of France, and Inspector-General of Mines, died in his sixty-eighth year. His work, which has had so wide an influence, covered the whole period of the rise of modern petrology. The systematic grouping of rocks was largely a French study at the opening of the nineteenth century; Michel Lévy carried on the tradition into far broader fields by concerning himself with their natural relationships and modes of origin. The great memoir entitled "Minéralogie micrographique; Roches éruptives françaises," in which he was associated with his master Fouqué, appeared in 1879 , and showed how the methods of Sorby had been appreciated in

No. 2 I90, vol. 87] 